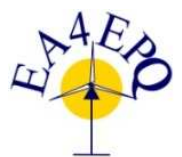

International Conference on Renewable Energies and Power Quality (ICREPQ'14) Cordoba (Spain), $8^{\text {th }}$ to $10^{\text {th }}$ April, 2014

Renewable Energy and Pourer (Quality. TournalRE\&PQJ)

ISSN 2172-038 X, No.12, April 2014

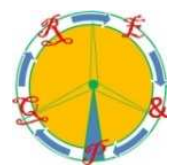

\title{
ANALYSIS OF ELECTRIC VEHICLES: A BRAZILIAN REALITY AND ITS CONSEQUENCES FOR THE ENVIRONMENT
}

\author{
Nilcéia Cristina dos Santos ${ }^{1}$, Carlos Eduardo Francischetti ${ }^{2}$, Reinaldo Gomes da Silva $^{3}$ \\ ${ }^{1}$ Faculdade de Tecnologia de Piracicaba "Dep. Roque Trevisan" (FATEC PIRACICABA) e \\ Universidade Metodista de Piracicaba (UNIMEP) \\ Phone number: +55 19 99614-1327 or +55 19 3411-2454 - E-mail: nilceia_santoss@yahoo.com.br, \\ ${ }^{2}$ Faculdades Integradas Einstein de Limeira (FIEL) / Universidade Paulista (UNIP) e \\ Universidade Metodista de Piracicaba (UNIMEP) \\ Phone number: +55 19 3454-2450 or + 5519 99746-5514 - \\ E-mail: cefrancischetti@gmail.com, cefranc@ibest.com.br \\ ${ }^{3}$ Escola de Engenharia de Piracicaba (EEP) \\ FUMEP, Fundação Municipal de Ensino de Piracicaba \\ Phone number: +55 19 99602-1218 - E-mail: reinaldorgda@gmail.com
}

\begin{abstract}
Environmental pollution affects climate change and cause various impacts on human health. The vehicles are among the main contributors to the problem. In Brazil, to combat this environmental pollution, public policy has been implemented in order to increase the efficiency of vehicles and diversify the use of alternative energy sources to fossil fuels (ethanol and biodiesel). On the other hand, the automakers developed electric and hybrid vehicles, which mix electricity with other fuel. This study aims to analyze the Brazilian market for electric vehicles, as well as their advantages and disadvantages in relation to environmental pollution.
\end{abstract}

KEYWORDS: electric vehicles, the automotive market, incentives, environmentally friendly solution, Brazil.

\section{INTRODUCTION}

In recent years, is increasing concerns related to climate change, mainly due to studies indicating that the energy balance has been influenced by various factors such as increase in the emission of greenhouse gases (GHGs), aerosols and solar radiation also. This increase is a result of increased use of fossil fuels and the earth, which increase the level of carbon dioxide $(\mathrm{CO} 2)$ in addition to increased emissions of methane $(\mathrm{CH} 4)$ and nitrous oxide (N2O) generated mostly by transport and agriculture and livestock (GONÇAVES, 2012).

These factors contribute to changes in the ecosystem, resulting in global warming, which triggers other problems, such as: reduction of polar ice caps, rising sea levels, increasing the greenhouse effect and other environmental distortions as tornadoes, droughts and torrential rains extensive areas that overflow and cause destruction in the cities where they occur. It is necessary to disseminate policies aimed at improving energy efficiency and emissions of gases that contribute to global warming (IPCC, 2007).
The burning of fuels by mobile sources aggravates the problem of air pollution in almost all major cities and represents a serious environmental problem, especially when it comes to developing countries. This pollution is caused by different factors, but the vehicles are among the main contributors to the problem, because they generate pollution and contaminate the environment. Currently, cars are responsible for $70 \%$ of all pollution generated in large cities such as Rio de Janeiro, Sao Paulo, Los Angeles, Mexico City, among others (MAYER, 1999).

In Brazil, there are policies that aim to increase the efficiency of vehicles, both new and used, and diversify the energy matrix by the use of alternative energy sources to fossil fuels (ethanol and biodiesel). There are also technology innovation on the part of auto companies that develop electric powered vehicles and hybrids that mix electricity with other fuel, but all are battery, fuel cell (hydrogen) or batteries (lead or lithium) (RIBEIRO AND REAL, 2006; RIBEIRO AND ABREU, 2008; SILVA, 2011).

In Brazil, despite the size of the automotive industry and the energy matrix favorable initiatives are in their infancy and the tendency is that the introduction of electric vehicles in the traffic of cities occurs in a timely manner and at a speed lower than expected by experts.

In this context, this study aims at analyzing the electric vehicle market in Brazil.

The methodology consists of an exploratory literature search performed through books, articles, theses and graduation projects, addressing the Brazilian automobile market, electric and hybrid vehicles, tax incentives Brazilian electric vehicles and automotive pollution.

Economic changes, technological, sociocultural and environmental why society has undergone seem to indicate a change in the role of vehicles, as well as transport people or cargo, it is necessary to cause the 
least possible impact on economic, social and environmental terms.

\section{LITERATURE REVIEW}

\section{A. Automobile Market in Brazil}

The first motor vehicle brought to Brazil arrived at the port of Santos in 1891, brought by Alberto Santos Dumont, who was then eighteen. The car was a Peugeot from France and was bought for 1,200 francs (PORTAL; INVESTE, 2012). Table 1 shows a brief history of the market and how it has the evolution of the automobile industry in Brazil.

Table 1 - The 10 Largest Producers of Cars and Commercial Vehicles in 2011.

\begin{tabular}{l|l|r|r|r}
\hline \multirow{2}{*}{ Position } & \multirow{2}{*}{ Country } & \multicolumn{2}{|c|}{ Produced vehicles } & \multirow{2}{*}{\begin{tabular}{c} 
light \\
\cline { 3 - 4 }
\end{tabular}} \\
\cline { 3 - 4 } & & Cars & \multirow{2}{*}{ Total } \\
\hline 1 & China & 14.485 .326 & 3.933 .550 & 18.418 .876 \\
\hline 2 & Japan & 2.966 .133 & 5.687 .427 & 8.653 .560 \\
\hline 3 & Germany & 7.158 .525 & 1.240 .129 & 8.398 .654 \\
\hline 4 & South Korea & 5.871 .918 & 4.394 & 5.876 .312 \\
\hline 5 & Índia & 4.221 .617 & 435.477 & 4.657 .094 \\
\hline 6 & U.S.A. & 3.053 .871 & 882.577 & 3.936 .448 \\
\hline 7 & Brazil & 2.534 .534 & 871.616 & 3.406 .150 \\
\hline 8 & France & 1.657 .080 & 1.022 .957 & 2.680 .037 \\
\hline 9 & Spain & 1.819 .453 & 534.229 & 2.353 .682 \\
\hline 10 & Rússia & 1.931 .030 & 363.859 & 2.294 .889 \\
\hline
\end{tabular}

In Brazil, there are several manufacturers that motorists are responsible for the production of cars, light commercials, trucks and buses. Most companies manufactures more than one type of product category, with the exception of Honda, Hunday and Toyota, who only do cars and Mahhindra and Mitsubischi only making light commercial vehicles. ANFAVEA (2013a). In Brazil, the automobile market has grown impressively in recent years, especially in the automobile segment. Net sales coming car went from U.S. \$ 10 billion in 1966 to U.S. \$ 50 billion in 1996 and U.S. $\$ 80$ billion in 2012. In the same period (19662012), agricultural machinery did not exceed the net revenues of U.S. \$ 10 billion (ANFAVEIA, 2013a).

The OICA (2012) made a survey of the largest producers of cars and commercial vehicles. China is the largest producer in the world, with $18,418,876$ units sold, a volume $46.98 \%$ more than Japan, placed second with 8,653,560 units. Brazil ranks seventh, with 2,680,037 units, 2,534,534 cars and 871,616 light commercial vehicles (OICA, 2012). Rao et al (2010) also show that the Brazilian automotive industry has evolved to the point of putting the country in fifth position in terms of the consumer market, the 12th in terms of exports and 13th when it comes to imports, is a leader in the production of vehicles using renewable fuels.
More than half of the cars produced in Brazil has 1.0 liter engine (ANFAVEA, 2013a). The government encourages the purchase of fuel-efficient vehicles by reducing the tax rate, which is a strong barrier to increasing the size of the fleet.

\section{B. Electric Vehicles and Hybrids}

Contrary to what many people believe the technology of hybrid and electric cars is not a recent technology innovation.

According to Hoyer (2008), the development of electric cars begins in mid-twentieth century, a time when the batteries are developed. In 1859, the Belgian Gaston Planté demonstrated the use of the first battery, made of lead and acid. This equipment came to be used in France, USA and UK for many electric vehicles developed from the beginning of 1880. In 1901 Thomas Edison developed the nickel-iron battery, with storage capacity $40 \%$ greater than the lead acid battery, but the cost of production was higher. The nickel-zinc and zincair were also created in the late nineteenth century.

At the time the electric vehicle was competitive in 1903, there were about four thousand cars registered in the city of New York, 53\% steam, 27\% gasoline and 20\% electric. In 1912, when the fleet of electric cars reached 30,000 units, but the amount of petrol cars was already thirty times larger (STRUBEN AND STERMAN, 2008).

According to DOE EIA (2009), some factors that happened at the time, contributed to the reduction in the share of electric cars in the automotive market, as follows:

a) Henry Ford implemented the system of mass production of gasoline-powered cars, a fact which reduced the price of the gasoline-powered car in $50 \%$ of the electric car;

b) In 1912, the electric starter replaced the hand crank used to drive vehicles with gasoline;

c) In 1920, in the U.S. are built roads connecting towns, which required autonomous vehicles to travel long distances;

d) The price of gasoline was reduced after the discovery of oil in Texas, making it attractive for the transport sector.

The restoration of electric vehicles returned only in mid1960 , when the population began to worry about the environment at that time, lead was used as a gasoline additive and no filters or catalysts, contributing to the car are the main sources air pollution. (BARAN AND LEGEY, 2010).

In 1970, three factors indicate the need to develop alternative renewable energy production: publication of the book "Limits to growth" that drew attention to a limit of exploitation of nonrenewable natural resources (1972), the oil crisis (1973) and awareness of the use of nuclear energy (safety and disposal of waste) (BARAN AND LEGEY, 2010).

In the late $1980 \mathrm{~s}$, electric vehicles were seen as a solution to the pollution of the big cities and as a 
salvation of the oil era, making the concept of sustainable development gains momentum, forcing the development of new energy sources, as well as a new means of transport (BARAN AND LEGEY, 2010).

In 1992, the Rio-92 occurs (ECO-92), this conference presented results document called Agenda 21. As proposed this conference, each country undertakes to reflect, locally and globally, on how companies, governments and sectors of society can work together to solve environmental problems. (BARAN AND LEGEY, 2010).

After this period, begins to emerge some hybrid vehicles, such as: Insight and Civic (Honda), the Prius (Toyota), Escape (Ford), Opel Ampera (GM) and others. According to Baran and Legey (2010), were sold in 2009, 598739 units and 44\% in the U.S., 41\% in Japan and the rest of the Netherlands, the UK and Canada. Sales of hybrids in the U.S. in 2008 represented slightly more than $4 \%$ of the U.S. market, totaling 279,847 units.

There are some variations of electric and hybrid cars, according ABVE (2013f) and Holland (2013) are some of them: Electric Car (EC) has at least one electric motor Electric Car Battery (CEB) has car batteries are charged by the network electricity; Hybrid electric Car $(\mathrm{CEH})$ to charge the batteries using electricity provided by a generator installed on the internal combustion engine (MCI); electric Car Hybrid "Plug-in" (CEHP) has more batteries and can be charged either the power grid using the generator combustion engine; electric Car fuel Cell (CECC) uses the energy generated by a hydrogen fuel cell to.

The most accepted of the hybrid vehicle was the $\mathrm{CEH}$, as well as reducing emissions to the combustion engine generates, it is quieter and has more autonomy, uses less fuel than similar vehicles with gasoline only. The CEB had a slower rate due to the batteries, because only recently they had become thinner, lighter and with a storage capacity greater energy, favoring rather the performance of the CEB. Some automakers are adopting CEHP, as it combines the best of electric cars, since it can be charged in both power grid as the combustion engine (HOLLAND, 2013).

\section{C.Electric Vehicles in Brazil}

In Brazil, the first attempt at large-scale production of electric vehicles occurred in the late 1970s and early 1980s, when the company Gurgel SA, in partnership with Furnas Central Electric SA has developed two models of electric cars: the Itaipu Electric and Itaipu 400. However, these models have not gained market share due to nationalization measures and the replacement of oil, as the Pro-Alcohol, as well as the high cost of vehicles and low autonomy (BORBA, 2011).

Currently in Brazil there is a government policy to stimulate the production or sale of these types of cars. The production of electrical restricted to small manufacturers bicyclic, buses and industrial vehicles and military, but with little range (BARAN, 2012).

In the city of São Paulo, in order to encourage the circulation of electric vehicles, they were exempted from prohibitions and limitations contained in the State Law 9,690 of June 2, 1997 and the State Decree 41,858 of June 12, 1997, which regulate program Restriction of Movement of motor Vehicles in the Metropolitan Region of São Paulo (vehicular in São Paulo / SP) (ABVE, 2013a).

Otherwise found to encourage the purchase of electric vehicles and reducing the level of $\mathrm{CO} 2$ emissions, was developed through the BNDES (National Bank for Economic and Social Development) a policy of financial support for the purchase of buses for transporting passengers municipal and metropolitan (ABVE, 2013a).

The consequence of these incentives is increased number of electric vehicles sold in Brazil according to (TABLE 1).

Table 1. Licensing of cars and light commercial vehicles - electrical

\begin{tabular}{c|c|c|c}
\hline MONTHS & $\mathbf{2 0 1 2}$ & $\mathbf{2 0 1 3}$ & $\begin{array}{c}\text { Variation } \\
\text { in \% }\end{array}$ \\
\hline Jan & 9 & 45 & 500,0 \\
\hline Feb & 16 & 22 & 137,5 \\
\hline Mar & 7 & 53 & 757,1 \\
\hline Apr & 3 & 50 & 1666,7 \\
\hline May & 13 & 12 & 92,3 \\
\hline Jun & 23 & 29 & 126,1 \\
\hline Jul & 5 & 65 & 1300,0 \\
\hline Aug & 3 & 45 & 1500,0 \\
\hline Sep & 2 & 23 & 1150,0 \\
\hline Oct & 2 & 39 & 1950,0 \\
\hline Nov & 18 & 52 & 288,9 \\
\hline Dec & 16 & & 0,0 \\
\hline Total & $\mathbf{1 1 7}$ & $\mathbf{4 3 5}$ & $\mathbf{3 7 1 , 7 9}$ \\
\hline ANFAVEA
\end{tabular}

Source: ANFAVEA (2013b)

(*)Includes both electric / external source, electric / hybrid and internal source (liquid fuel / electric).

The amount of electric vehicles sold in Brazil increased $371,79 \%$ in 2013 , compared with 2012. Although this percentage representative, they represent some of the volume of 3.77 million vehicles sold in Brazil between december/2012 to november/2013 (ANFAVEA, 2013b). This is a reality quite different from that found in the European market, where despite market plug-in electric vehicles (PEVs) have grown more slowly than expected, in 2013 the fleet willdouble to 70 thousand units, with 14,000 only in Germany (ABVE, 2013b).

The main reason for having so few electric cars circulating in Brazil is the high burden of taxes on the final price is $35 \%$ import tax, plus $55 \%$ of IPI, over $13 \%$ of PIS / COFINS, another 12 to $18 \%$ of VAT, depending on the state, so the taxation on electric cars exceed $120 \%$ (ABVE, 2013b). With this, the average price today of an electric car sold in Brazil reaches $\mathrm{R} \$$ 200000 (two hundred thousand reais), which corresponds to $\$ 90,000$ (ninety thousand U.S. dollars) 
considering the price of the exchange rate Real / Dollar 25/10/2013 where U.S.\$ 1.00 (one U.S. dollar) equivalent to $\mathrm{R} \$ 2.20$ (two real and twenty cents).

Baran (2012) noted that the acceptance by the defilement Brazilian automobile ethanol and flex-fuel, can be assumed that an alternative automotive technology, such as hybrid and electric, has the potential to spread in a few years, since properly stimulated by the government. In the case of the electric stimuli could be given: (a) tax relief, to reduce the final price to the consumer, (b) disseminate recharge points, (c) guarantee competitive price for electricity, and (d) in encouraging the spread of smart grid in Brazil.

Currently, a major obstacle to the introduction of the electric car in Brazil is competition with biofuels program, especially ethanol, and the oil recently discovered the so-called pre-salt (BARAN, 2012).

\section{D.Brazilian tax incentives for electric vehicles}

In Brazil, in the states of Ceará (Law 12.023), Maranhão (Law 5.594), Pernambuco (Law 10,849), Piauí (Law 4.548), Rio Grande do Norte (Law 6.967), Rio Grande do Sul (Law 8.115) and Sergipe (Law 3.287) for an exemption from collecting the property taxes (Property Tax motor Vehicle) for electric vehicles or electric motive power. In other states (Mato Grosso do Sul, Rio de Janeiro and São Paulo) as a way to stimulate the sale of vehicles, was granted a reduction of property taxes, applying different tax rates. (ABVE, 2013a).

The Social Affairs Committee (CAS) approved the Draft Law No. 255 of 2010 Senator Roberto Cavalcanti suspending the collection of the Tax on Industrialized Products (IPI) for ten years for hybrid vehicles or powered by electricity that are manufactured in Brazil, as well as accessories used in its manufacture. There is also the total reduction in the rate of contributions to the Social Integration Program and Training of Civil Servants Asset (PIS / PASEP) and Contribution for Social Security Financing (COFINS) levied on gross revenues from the sale, in the domestic market of electric and hybrid vehicles (CAVALCANTI, 2010).

Congressman Ronaldo Benedet created the Bill 3.895/12 which creates energy for the dealer automotive purposes. With that, may be used in Brazil and the CEB CEHP, it is proposed that this activity can be exercised by the licensee or permittee of public electricity distribution or reseller retail electricity registered with the National Agency of Electric Energy (ANEEL) (CAMARA, 2012).

In Brazil, the tax on cars reaches $30.4 \%$, six times more than the U.S.A. (5.7\%) and three times higher than in Japan $(9.1 \%)$, and almost double that of countries like Italy , Spain, UK, France and Germany (average 16\%) (ANFAVEA, 2013a).

Erber (2010, p. 105) presents the estimates (see Table 2) for the sale of electric vehicles in Brazil in the next 20 years.
Table 2. Estimates of sales of electric vehicles in Brazil (in million units)

\begin{tabular}{c|c|c|c}
\hline Year & $\begin{array}{c}\text { Total vehicles } \\
\text { (electric and } \\
\text { non-electric) }\end{array}$ & $\begin{array}{c}\text { Hybrid electric } \\
\text { vehicle }\end{array}$ & $\begin{array}{c}\text { Eectric vehicle } \\
\text { to the battery } \\
\text { and plug-in }\end{array}$ \\
\hline 2010 & 2,8 & 0 & 0 \\
2015 & 3,6 & 0,1 & 0,04 \\
2020 & 4,2 & 0,73 & 0,3 \\
2025 & 4,9 & 1,39 & 1,31 \\
2030 & 5,6 & 1,65 & 2,46 \\
\hline
\end{tabular}

Source: based Erber (2010, p. 105).

The exemption or reduction of tax rates on the sale price of the car is essential for the increase in the quantity sold, even for those who are not electrical.

\section{E.Consequences to the environment}

Electric vehicles (hybrid or battery), in general, are more efficient and less harmful to the environment than cars with internal combustion.Although the batterypowered vehicles emit $0 \%$ of pollutants and be silent, are more expensive than hybrid and its use is limited to short paths, hence its use in restricted areas such as condominiums and shopping malls (BORTOLOTI et al, 2013).

According to GRUVE (2002), the aspects that call attention to electric vehicles are: Smokeless, be silent; absence of grease and dirt on parts motor propulsion; rates have not; being refueled by electricity from a wall outlet ; radiator and not, or do not require water or oil.

The main components of electric vehicles is the battery, controller and electric motor speeds itself. Table 2 shows the most commonly used batteries, highlighting their advantages and disadvantages, with their chemical compounds.

Table 2 - Batteries, compounds, advantages and disadvantages.

\begin{tabular}{|c|c|c|}
\hline $\begin{array}{l}\text { BATTERY } \\
\text { MODEL }\end{array}$ & ADVANTAGES & DISADVANTAGES \\
\hline Lead & The cost is not high. & $\begin{array}{l}\text { Low energy density due } \\
\text { to the weight of lead. }\end{array}$ \\
\hline Nickel Metal & $\begin{array}{l}\text { Long life. Resistance to } \\
\text { loading and unloading, and } \\
\text { its components are not } \\
\text { harmful to the environment. }\end{array}$ & \multirow{2}{*}{$\begin{array}{l}\text { Depending on the } \\
\text { discharge cycle life can } \\
\text { be exhausted quickly. If } \\
\text { the nickel price increase } \\
\text { prevents the mass sale. }\end{array}$} \\
\hline Nickel Zinc & $\begin{array}{c}\text { High, environmentally clean } \\
\text { and recyclable energy } \\
\text { density. }\end{array}$ & \\
\hline Nickel Cadmium & $\begin{array}{l}\text { Long lifetime and total } \\
\text { discharges of energy. }\end{array}$ & $\begin{array}{l}\text { High cost. Cadmium is } \\
\text { harmful to the } \\
\text { environment. }\end{array}$ \\
\hline Lithium Ion & $\begin{array}{l}\text { High energy capacity and } \\
\text { long life. }\end{array}$ & $\begin{array}{l}\text { High cost. Need for } \\
\text { electronic circuit to } \\
\text { control load and } \\
\text { temperature. }\end{array}$ \\
\hline
\end{tabular}

Source: Bortoloti et al (2013, p. 13).

Lithium ion batteries provide autonomies 150-200 kilometers; those of lead-acid type, 50-70 km. However, for most urban users, this autonomy can be an impediment, because it exceeds their daily routes, making it difficult to travel long distances to the vehicle without the need to recharge in your SAE (System Energy Storage) (ABVE, 2013d, 2013f). 
As the autonomy of electric vehicles is low, there is the need to create stations refills on public roads and residential or commercial environments. The Draft Law 4751/12, authored by Mr Heuler Cruvinel (GO) and Santo Onofre Agostini (SC) requires federal agencies to set technical standards for these charging points, considering the constant technological changes in the industry (ABVE, 2013e).

To meet this need, Schneider Electric, a French company, promises to build by the end of 2013, charging stations in homes or offices for electric vehicles in Brazil (AUTODATA, 2013).

The Brazilian Association of Technical Standards (ABNT) published on June 3, 2013, ABNT NBR IEC 61851 which regulates conductive charging system for electric vehicles. It is the work of the Study Committee 03:069.01 - Electric road vehicles and industrial, coordinated by the Brazilian Committee on Electricity (ABNT/CB-03), this standard has three parts (1:2013, 21:2013 and 22: 2013 regulating the charging voltage (ABVE, 2013c):

The electric vehicle is not composed solely of benefits, there is concern about the source of electricity that will trigger these cars. Although more than $85 \%$ of the electricity generated in Brazil comes from renewable sources, the long-term participation of thermoelectric generation from fossil fuels is expected to increase. The concern with the increased consumption of these fuels is appropriate, and is being questioned (ABVE, 2013d).

In Brazil, the expansion of the electric car battery market follows a relatively slow compared to other countries and the electricity sector will certainly be able to meet the additional demand arising. To illustrate, if $10 \%$ of the current car fleet was made up of electric cars would require an increase in power generation of around $2 \%$, so until the demand for these vehicles becomes significant, the power sector would be able to providing your care (ABVE, 2013d).

Another disadvantage is related to the battery for the car to be more efficient are the ideal lithium ion, but besides being expensive, it is a non-renewable mineral and there are large reserves of him (ABVE, 2013d). Also, take into account recycling automotive batteries lead acid already have procedures and processes to make the recycling, but the lithium-ion are just beginning as recycling. The process is not simple, but there are already some companies making the collection and recycling of rechargeable lithium-ion (ABDI, 2009).

According to Mulliken (2009), the U.S. Department of Energy gives the company Toxco $\$ 9.5$ million to build a plant for the recycling of lithium-ion batteries for hybrid vehicles. The recycling of the battery is complex, it requires the storage of the battery in concrete bunkers to a cryogenic process that cools the battery $198^{\circ}$ Celsius, making it inert to the disassembly process. As a rule of operational safety, the use Toxco about $90 \%$ of cases remotely operated robots.

In Brazil, the National Council for the Environment (CONAMA) targeting the correct disposal developed ${ }^{\circ}$ Resolution No. 257, which came into force in June
2000 , it aims to regulate and regulate the disposal of batteries, which after its energy depletion should be delivered to the stores that sell them, so that they give back to the manufacturers or importers to carry the reverse logistics and make the procedures for reuse, recycling, treatment and environmentally sound disposal. There is no mention of lithium batteries if they need to be recycled or not (CONAMA, 2013).

\section{FINAL CONSIDERATIONS}

The proposed objective in this study was to analyze the electric vehicle market in Brazil.

First, we sought to know about the Brazilian automobile market, where we identified the companies operating in the country, the types of vehicles produced, and data in this sector in the country and its representation in the global automotive vehicles.

On electric and hybrid vehicles, it was identified that there is a recent technology, it is more than a century, and for economic reasons was dropped, returning with force only recently, due to the environmental appeal by which all sectors are being charged.

In Brazil, the segment of electric and hybrid vehicles, despite an increase of $294 \%$ in sales in 2013 compared to 2012 , the quantity sold does not exceed 350 units, is an insignificant number given the grandeur of the Brazilian automobile market. To encourage the sale of these vehicles, there are several laws exempting or reducing taxes on production, yet the final sale price to the consumer is high, hindering their large-scale commercialization.

Finally, this study assessed the impact that the use of these vehicles can bring to the environment. There are several advantages, such as being silent and will not emit pollutants or use grease. One of the disadvantages mentioned is in relation to the use of electricity, which depending on the type of plant used to generate electricity contributes to the increase in greenhouse gases, generates radioactive waste, environmental impact on rivers and promote deforestation. Another disadvantage is regarding the batteries used that require a recycling process (reverse logistics), and the problem of lithium ions, which is a non-renewable mineral and battery made of this material has a recycling process costly.

Some programs are being tested in Brazil for the use of electric vehicles, for example, since December 2012 there are 10 electric vehicles composing the fleet of taxi in São Paulo (SP), in September 2013 a system of rental electric cars was deployed in Curitiba (PR), and in October 2013 in Salvador $(\mathrm{BH})$ are circulating two electric buses.

This study is not conclusive, as the use of electric and hybrid vehicles is incipient in Brazil, there is the need to collect more information about the barriers to entry for this type of product on the existence of more projects underway laws that facilitate marketing of these products, an economic-financial distribution of such vehicles in the country, compare the costs with the electric recharge in relation to the supply of fuel (gasoline, ethanol, diesel and natural gas), as well as a 
survey of the population to mount a overview of the sales of these vehicles.

\section{ACKNOWLEDGEMENT}

Financial support of the Coordination of Improvement of Higher Education Personnel (CAPES), Process AEX 15.110/13-3

\section{REFERENCES}

[1] ABDI - Agência Brasileira de Desenvolvimento Industrial. Relatório de perspectivas: estudo prospectivo setorial automotivo. Brasília: Centro de Estudos Estratégicos, 2009.

[2] ABVE - Associação Brasileiras dos Veículos Elétricos. Legislação para veículos elétricos no Brasil. (2013a). Disponível em: 〈http://www.abve.org.br/incentivos.asp〉. Acesso em: 05/08/2013.

[3] ABVE - Associação Brasileiras dos Veículos Elétricos. Veículos elétricos: previsões para 2013. (2013b). Disponível em: <http://www.abve.org.br/destaques/2013/destaque13002.asp〉. Acesso em: 05/08/2013.

[4] ABVE - Associação Brasileiras dos Veículos Elétricos. ABNT publica norma técnica para recarga de veículos elétricos no Brasil. (2013c). Disponível em: <http://www.abve.org.br/destaques/2013/destaque13016.asp>. Acesso em: 05/08/2013.

[5] ABVE - Associação Brasileiras dos Veículos Elétricos. Carro Elétrico vale a pena? (2013d). Disponível em: <http://www.abve.org.br/destaques/2012/destaque12035.asp〉. Acesso em: 05/08/2013.

[6] ABVE - Associação Brasileiras dos Veículos Elétricos. Brasil pode exigir estações de recarga para veículos elétricos em $2014 . \quad$ (2013e). Disponível em: <http://www.abve.org.br/destaques/2013/destaque13005.asp〉. Acesso em: 05/08/2013.

[7] ABVE - Associação Brasileiras dos Veículos Elétricos. O que é veículo elétrico híbrido? (2013f). Disponível em: $\langle$ http://www.abve.org.br/PF/ExibePF.asp?codigo=0003〉. Acesso em: 05/08/2013.

[8] ANFAVEA. Brazilian Automotive Industry Yearbook. 2013a Disponível em: <http://www.anfavea.com.br/anuario.html> Acesso em: 06/10/2013.

[9] ANFAVEA. Carta da Anfavea - Dezembro/2013. 2013b. Disponível em: <http://www.anfavea.com.b /cartas/Carta331.pdf >. Acesso em 27/12/2013.

[10] AUTODATA. Brasil poderá ganhar estações de recarga para veículos elétricos. Disponível em: <http://www.sindmetau.org.br/site/index.php/empresas/17214brasil-podera-ganhar-estacoes-de-recarga-domestica-paraveiculos-eletricos.html>. Acesso em: 20/09/2013.

[11] BARAN, Renato. Introdução de veículos elétricos no Brasil: avaliação do impacto no consumo de gasolina e eletricidade.2012, p. 124. Tese (Doutorado do Programa de Planejamento Energético/COOPE) - Universidade Federal do Rio de Janeiro (UFRJ), Rio de Janeiro. 2012

[12] BARAN, Renato; LEGEY, Luiz F. L. Veículos elétricos: história e perspectivas no Brasil. BNDES Setorial 2010, n. 33, p. 207224.

[13] BORBA, Bruno Soares Moreira Cesar. Modelagem integrada da introdução de veículos leves conectáveis à rede elétrica no sistema energético brasileiro.2011. 166p. Tese (Doutorado do Programa de Planejamento Energético/COOPE) - Universidade Federal do Rio de Janeiro (UFRJ), Rio de Janeiro. 2011.

[14] BORTOLOTI, Márcio A, et al. Veículos híbridos uma solução ecológica ou não? Estudo comparativo do ciclo de vida de dois produtos substitutos com tecnologias diferentes: veículos com motor flex e híbridos. In. ENCONTRO NACIONAL DA ASSOCIAÇÃO NACIONAL DOS CURSOS DE GRADUAÇÃO EM ADMINISTRAÇÃO, XXIV, 2013, Florianópolis. Anais....Florianópolis, 2013.

[15] CAMARA dos Deputados. PL 3895/2012. 22/05/2012. Disponível <http://www.camara.gov.br/proposicoesWeb/fichadetramitacao?i dProposicao $=545232>$. Acesso em: 09/09/2013.

[16] CAVALCANTI, Roberto. PLS - PROJETO DE LEI DO SENADO, $\mathrm{N}^{\mathbf{0}} 255$. Concede benefícios fiscais referentes àimpostos que incidentes sobre operações com veículos híbridos ou movidos a tração elétrica, suas partes e acessórios. 19/10/2010. Disponível em: $<$ http://www.senado.gov.br/atividade/materia/detalhes.asp?p_cod mate $=98179>$. Acesso em: 10/04/2013.

[17] CONAMA - Conselho Nacional do Meio Ambiente. Resoluções do CONAMA: resoluções vigentes publicadas entre setembro de 1984 e janeiro de 2012. Ministério do Meio Ambiente. Brasília: MMA, 2012.

[18] EIA DOE. Annual Energy Review,2009. Disponível em: $<\mathrm{http} / / / \mathrm{www}$.eia.doe.gov/emeu/aer/contents.html. Acesso em: 20/04/2013.

[19] ERBER, PIETRO. 2010. Automóveis elétricos a bateria: uma política para sua utilização no Brasil. In: João Paulo do Reis Velloso (Coord.), Estratégia de implantação do carro elétrico no Brasil. Rio de Janeiro: Instituto Nacional de Altos Estudos (INAE), Cadernos Fórum Nacional 10, 2010. p. 87-116.

[20] GONÇALVES, José Manoel Ferreira. Cenários possíveis para o transporte de açúcar e de contêineres para o porto de Santos visando a redução das emissões de gases de efeito estufa. 2012, p. 544. Tese (Doutorado em Engenharia de Produção) Universidade Metodista de Piracicaba (UNIMEP), São Paulo. 2012.

[21] GRUVE - Grupo de Estudos de Veículos Elétricos. Veículos elétricos: um caminho para diminuir a poluição do ar. 2002. Disponível em: 〈http://www.gruve.eng.uerj.br/uerjsmuros.pdf>. Acesso em: 14/08/2013

[22] HOLlANDA, Jayme Buarque de. O futuro dos Carros Elétricos. Um artigo para eu ler daqui a 10 anos. 2013.Disponível em: <http://www.abve.org.br/downloads/O_futuro_dos_Veiculos_Elet ricos.pdf>. Acesso em: 27/10/2013.

[23] HOYER, Karl Georg.(2008).The History of Alternative Fuels in Transportation: The Case of electric and Hybrid Cars. Utilities Policy. n. 16, p. 63-71.

[24] INVESTE São Paulo. Agência Paulista de Promoção de Investimentos e Competitividade. 2012. Disponível em: <http://www.investe.sp.gov.br/setores/automotivo〉. Acesso em: 01/07/2013.

[25] IPCC. Climate Change (2007). Synthesis Report. Contribution Of Working Groups I, II and III to the Fourth Assessment Report of the Intergovernmental Panel on Climate Change [Core Writing Team, Pachauri, R.K. and Reisinger, A. (eds.). IPCC, Geneva Switzerland, $104 \mathrm{p}$.

[26] MAYER, Helmut. 1999. Air pollution in cities. Atmospheric Environment. v.33, n. 24-24, p. 4029 - 4037.

[27] MULLIKEN, Bruce. Recycle lithium today for tomorrow's cars. Green Energy News. v.14, n.6, 2009.

[28] OICA, 2012, International Organization of Motor Vehicle Manufacturers,Disponível

em:<http://oica.net/category/production-statistics/>.Acesso em 16 de junho de 2012

[29] PORTAL do Governo do Estado de São Paulo. Indústria Automobilística. 2012. Disponível em: <http://www.saopaulo.sp.gov.br/conhecasp/historia_republicaindustria-automobilistica>. Acesso em: 05/04/2013.

[30] REZENDE, Sérgio et al (2010). Os veículos elétricos e as ações do Ministério da Ciência e Tecnologia. In: João Paulo do Reis Velloso (Coord.), Estratégia de implantação do carro elétrico no Brasil. Rio de Janeiro: Instituto Nacional de Altos Estudos (INAE), Cadernos Fórum Nacional 10, 2010. p. 87-116.

[31] RIBEIRO, Suzana K.; REAL, Márcia V.. Novos Combustíveis. Rio de Janeiro: E-papers, 2006.

[32] RIBEIRO, Suzana K.; ABREU, Adrianna. A. (2008). Brazilian Transport Initiatives with GHG Reductions as a co-benefit. Climate Policy.v.8, n.2, p. 220-240.

[33] SILVA, Elenice Rachid. Análise do crescimento da motorização no Brasil e seus impactos na mobilidade urbana 2011. 142p. Dissertação (Mestrado do Programa de Planejamento Energético/COOPE) - Universidade Federal do Rio de Janeiro (UFRJ), Rio de Janeiro. 2011.

[34] STRUBEN, Jeroen; STERMAN, John. D. (2008).Transition challenges for alternative fuel vehicle and transportation systems.Environment and Planning B: Planning and Design, v.35, n.6, p. 1070-1097. 